$\mathrm{A} \mathrm{J}_{\mathrm{sins}} \mathrm{H}$

Received : 14.01.2015

Accepted : 24.05.2015
THEASIAN JOURNAL OF HORTICULTURE

Volume 10 | Issue 1 | June, 2015 | 173-176

Visit us -www.researchjournal.co.in
A CASE STUDY

DOI : 10.15740/HAS/TAJH/10.1/173-176
Members of the Research Forum

Associated Authors:

${ }^{1}$ Department of Horticulture, Pandit Jawaharlal Nehru College of

Agriculture and Research Institute,

KARAIKAL (U.T. OF PUDUCHERRY)

INDIA

Email : sundaramsvn@yahoo.co.in

Author for correspondence : P. RAJKUMAR

Department of Horticulture, Pandit Jawaharlal Nehru College of

Agriculture and Research Institute,

KARAIKAL (U.T. OF PUDUCHERRY)

INDIA

Email : rajkumarp65@gmail.com

\section{Genetic analysis in okra [Abelmoschus esculentus (L.) Moench]}

\section{P. RAJKUMAR AND V. SUNDARAM ${ }^{1}$}

ABSTRACT : Study of thirty three diverse genotypes of okra revealed the presence of high variability, for primary branches at flowering, internodal length, leaf area index, mucilage content, seed number and hundred seed weight. The traits viz., days to flowering, plant height, primary branches at flowering, internodal length, relative water content, mucilage content, crude fibre content, pedicel length, fruit length, fruit girth, fruit weight, seed number and hundred seed weight were found to be highly heritable and hence, could be considered while selection. High heritability with high genetic gain observed for plant height, primary branches at flowering and internodal length indicate the predominance of additive genes, while high heritability with low genetic gain observed for days to flowering indicate the role of non-additive gene action.

KEY WORDS : Okra, Genotypic co-efficient of variation (GCV), Phenotypic co-efficient of variation $(\mathrm{PCV})$, Heritability, Genetic gain

HOW TO CITE THIS ARTICLE : Rajkumar, P. and Sundaram, V. (2015). Genetic analysis in okra [Abelmoschus esculentus (L.) Moench]. Asian J. Hort., 10(1) : 173-176. 